\title{
Stepwise methane-to-methanol conversion on CuO/SBA-15
}

\author{
Ha V. Le, ${ }^{[a]}$ Samira Parishan, ${ }^{[b]}$ Anton Sagaltchik, ${ }^{[c]}$ Hamideh Ahi, ${ }^{[c],[d]}$ Annette Trunschke, ${ }^{[d]}$ Reinhard \\ Schomäcker, ${ }^{[b]}$ and Arne Thomas ${ }^{*[a]}$
}

\begin{abstract}
The direct partial oxidation of methane to methanol is a great scientific and economical objective to expand the application of the abundant fuel gas as a major resource for one-step production of value-added chemicals. Despite substantial efforts to commercialize this synthetic route, to date, no heterogeneous catalyst can selectively oxidize methane into methanol by $\mathrm{O}_{2}$ with an economically acceptable conversion. Cu-exchanged zeolites have been recently highlighted as one of the most promising bioinspired catalysts toward the direct production of methanol from methane under mild conditions. In this work, we prepared Cu-based catalysts using SBA-15 as an alternative support and investigated their activity for this conversion. Our results demonstrate that highly dispersed $\mathrm{CuO}$ species on SBA-15 are able to react with methane and subsequently produce methanol with high selectivity (> $84 \%$ ) via water-assisted extraction. Furthermore, it is confirmed that the main intermediate formed after interaction of the catalyst with methane is a methoxy species, which can be further converted to methanol or dimethyl ether (DME) upon extraction with water or methanol, respectively.
\end{abstract}

\section{Introduction}

As supplies of crude oil are declining, methane, which is the major component of abundant resources such as natural gas, methane hydrates, and biogas, has emerges as a potential alternative feedstock for the chemical industry. ${ }^{[1]}$ However, methane is not widely utilized on a commercial scale because of its high chemical inertness. ${ }^{[2]}$ In the current energy-intensive route, methane is first converted to syngas typically at $1000{ }^{\circ} \mathrm{C}$ and 30 bar, which can subsequently be transformed to methanol and hydrocarbons via hydrogenation and Fischer-Tropsch synthesis, respectively. ${ }^{[3]}$ Developing an alternative process to produce value-added chemicals, such as methanol from methane, preferably in one step, has been therefore a research field of increasing interest in recent years. Unfortunately, direct

[a] Ha V. Le, Prof. Dr. Arne Thomas Institute of Chemistry-Functional Materials, BA2 Technische Universitat Berlin,

Hardenbergstraße 40, 10623 Berlin (Germany) E-mail: arne.thomas@tu-berlin.de

[b] S. Parishan, Pro. Dr. Reinhard Schomäcker Institute of Chemistry- Technical Chemistry, TC8 Technische Universitat Berlin,

Straße des 17. Juni 124, 10623 Berlin, (Germany)

[c] A. Sagaltchik, Dr. H. Ahi

BasCat-UniCat BASF Joint Lab, Technische Universitat Berlin, EW $\mathrm{K} 01$

Hardenbergstraße 36, 10623 Berlin (Germany)

[d] Dr. H. Ahi, Dr. Trunschke

Department of Inorganic Chemistry, Fritz Haber Institute of the Max Planck Society

Faradayweg 4-6, 14195 Berlin (Germany)

Supporting information for this article is given via a link at the end of the document. oxidation strategies showed low yields and productivity due to the much higher reactivity of the oxygenated products compared to methane. $\left.{ }^{[1 a}, 3 a, 4\right]$ Efficient activation of methane at milder conditions and control of reaction selectivity toward the desired products are therefore the main challenges in heterogeneous catalysis.

Biological catalysts have motivated many researchers to tackle these challenges. Methane monooxygenase enzymes (MMOs) in methanotropic bacteria are able to consume methane as their sole source of both carbon and energy, selectively oxidizing methane to methanol under ambient conditions by atmospheric $\mathrm{O}_{2}{ }^{\left[{ }^{[5]}\right.}$ Two forms of MMOs are located at different cellular positions, including cytoplasmic MMOs (soluble form) and membrane-bound MMOs (particulate form). A bis( $\mu$-oxo)diiron core is known as the active site in the soluble MMOs while the particulate form contains di- and tricopper clusters that efficiently activate the $\mathrm{C}-\mathrm{H}$ bond of methane. ${ }^{[6]}$ Inspired by these prototype natural machines, in the last decade, $\mathrm{Cu}-, \mathrm{Co}-$ and $\mathrm{Fe}$ exchanged zeolites have been used as heterogeneous catalysts for the methane-to-methanol conversion due to their ability to activate methane at low temperatures and reveal high selectivities to methanol. This is typically achieved in a stepwise process, in which the catalyst is first oxidized in $\mathrm{O}_{2}$ or $\mathrm{N}_{2} \mathrm{O}$ at high temperatures $\left(>200{ }^{\circ} \mathrm{C}\right)$, and then reacts with methane at lower temperatures $\left(\leq 200{ }^{\circ} \mathrm{C}\right)$. The subsequent transformation of the formed intermediate stabilized on the catalyst surface to methanol is performed via a final treatment with water. ${ }^{[7]}$ As the so far most active catalysts, Cu/zeolites have been intensively studied to identify the possible structures of active $\mathrm{Cu}$ sites and the catalytic mechanisms to finally develop improved procedures. ${ }^{[6 a, 7 d, 8]}$ To expand this promising material class, we report here the first demonstration of methane-to-methanol conversion over an SBA-15-supported Cu catalyst. Unlike Cuoxo complexes in $\mathrm{Cu} / z e o l i t e s$ previously suggested as the active sites for the hydroxylation of methane, the catalytic activity of $\mathrm{CuO} / \mathrm{SBA}-15$ is attributed to small $\mathrm{CuO}$ nanoclusters that are highly dispersed throughout the SBA-15 framework. Our results are expected to accelerate the development of novel Cu-based catalysts using other supports than zeolites for this "dream reaction".

\section{Results and Discussion}

Cu species were supported on SBA-15 by wet impregnation. In detail, the catalyst synthesized from $\mathrm{Cu}(\mathrm{II})$ acetylacetonate $\left(\mathrm{Cu}(\mathrm{acac})_{2}\right)$ was named $\mathrm{Cu}-\mathrm{AA} / \mathrm{SBA}$ while the one obtained using $\mathrm{Cu}(\mathrm{II})$ acetate $\left(\mathrm{Cu}(\mathrm{OAc})_{2}\right)$ was named $\mathrm{Cu}-\mathrm{OA} / \mathrm{SBA}$. Similar $\mathrm{Cu}$ loadings ( 2.7 wt.\%) were obtained for both $\mathrm{Cu}$ AA/SBA and Cu-OA/SBA.

The PXRD pattern at low angles of the unloaded SBA-15 showed three diffraction peaks indexed as (100), (110), and (200) plane corresponding to the well-ordered two-dimensional hexagonal structure of SBA-15 (Figure 1a). ${ }^{[9]}$ The (100) diffraction peak was as well observed in the for both $\mathrm{CuO} / \mathrm{SBA}$ - 
15 materials, indicating that the porous structure of the SBA-15 pore was sustained during impregnation. The decreased intensity of the peaks for Cu-containing samples can be attributed to the presence of $\mathrm{Cu}$ species in the SBA-15 channels. ${ }^{[10]}$ Wide-angle XRD measurements of the CuO/SBA15 samples showed different results, depending on the used $\mathrm{Cu}$ (II) precursors (Figure 1b). No obvious peaks for any crystalline phase are observed for Cu-AA/SBA, which indicates that the $\mathrm{Cu}$ species are well-dispersed on the support. In contrast, the diffractogram for Cu-OA/SBA shows to peaks at $2 \Theta$ $=36^{\circ}$ and $39^{\circ}$ indicative of the formation of $\mathrm{CuO}$ particles on the support.
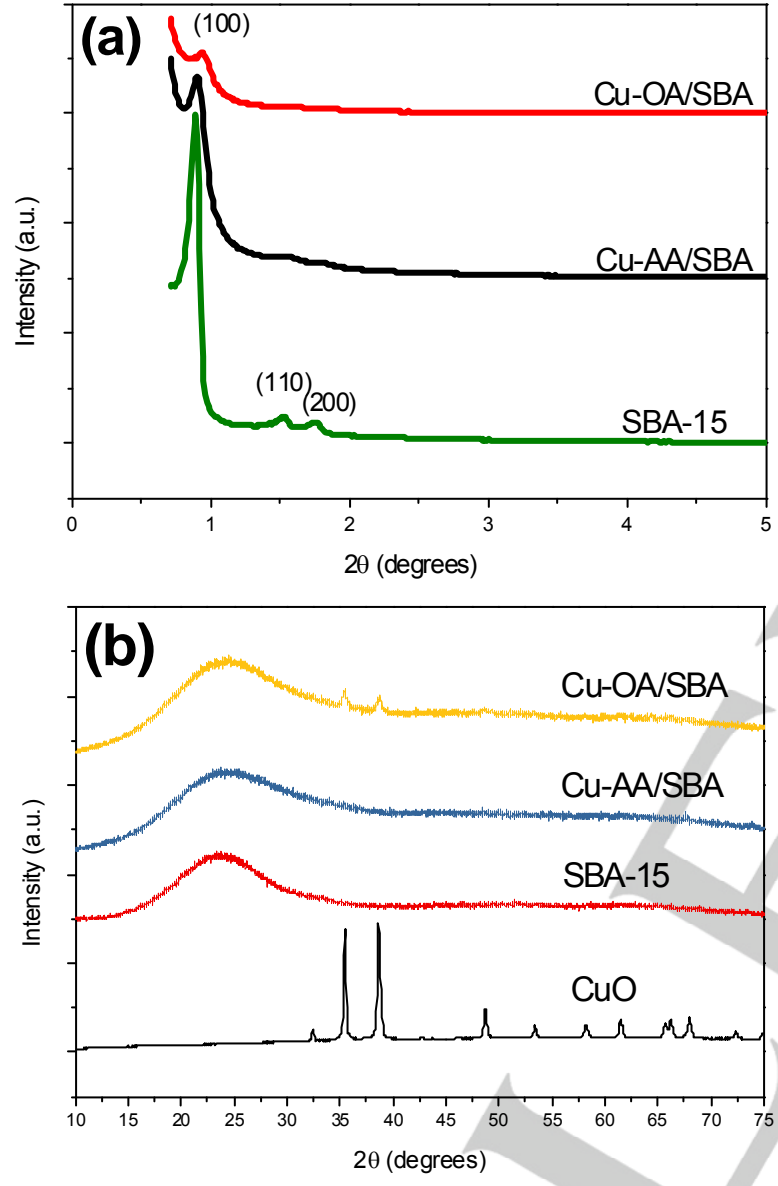

Figure 1. PXRD patterns at (a) low angles and (b) wide angles of the materials.

The structure of the CuO/SBA-15 samples was further investigated by TEM measurements. Regular hexagonal mesochannels are seen for all samples, before and after impregnation and calcination (Figure 2). No nanoparticles are detected in the TEM images of Cu-AA/SBA (Figure 2b) while nanoparticles with various sizes $(10-50 \mathrm{~nm})$ are obviously seen the Cu-OA/SBA sample (Figure 2c). Nitrogen sorption measurements show a decrease of surface area and total pore volume after the impregnation of the $\mathrm{Cu}$ species into SBA-15, which is found to be more significant for Cu-AA/SBA (Table 1). In addition, both mesopore and micropore volumes of $\mathrm{Cu}$ AA/SBA are lower than those of $\mathrm{Cu}-\mathrm{OA} / \mathrm{SBA}$, respectively. In combination with TEM and XRD results, it can be concluded that
$\mathrm{Cu}$ species are indeed mainly located within the pores of $\mathrm{Cu}$ AA/SBA while for $\mathrm{Cu}-\mathrm{OA} / \mathrm{SBA}$ larger $\mathrm{CuO}$ nanoparticles are also located on the outer surface of SBA-15.
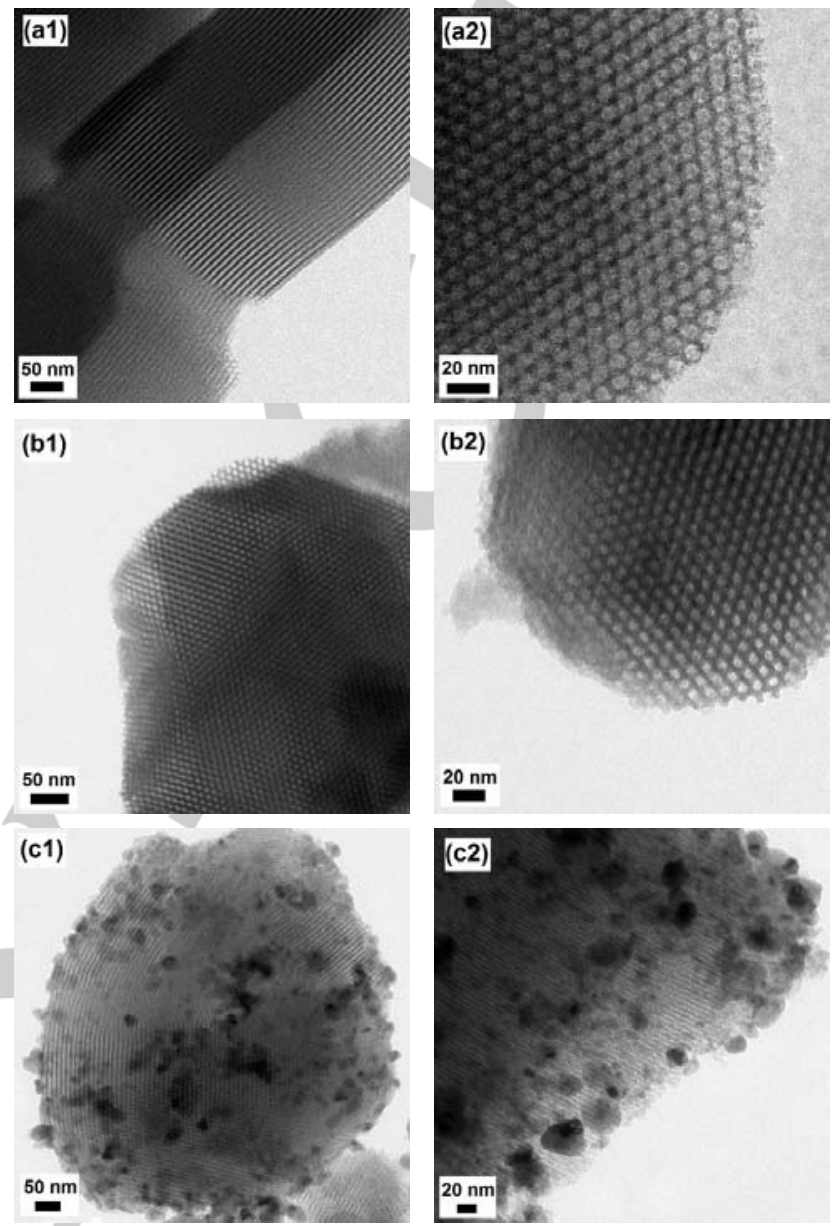

Figure 2. TEM images of (a1, a2) pure SBA-15, (b1, b2) calcined Cu-AA/SBA, and $(\mathrm{c} 1, \mathrm{c} 2)$ calcined $\mathrm{Cu}-\mathrm{OA} / \mathrm{SBA}$.

Table 1. Textural properties of SBA-15-based materials.

\begin{tabular}{cccccc}
\hline Sample & $\begin{array}{c}\mathrm{Cu} \\
\text { loading } \\
(\text { wt. \% })\end{array}$ & $\begin{array}{c}\mathrm{SA}^{[\mathrm{a}]} \\
\left(\mathrm{m}^{2} \mathrm{~g}^{-1}\right)\end{array}$ & $\begin{array}{c}\mathrm{V}_{\text {meso }}{ }^{[\mathrm{b}]} \\
\left(\mathrm{cm}^{3} \mathrm{~g}^{-1}\right)\end{array}$ & $\begin{array}{c}\mathrm{V}_{\text {micro }}{ }^{[\mathrm{b}]} \\
\left(\mathrm{cm}^{3} \mathrm{~g}^{-1}\right)\end{array}$ & $\begin{array}{c}\mathrm{V}_{\text {total }}{ }^{[\mathrm{c}]} \\
\left(\mathrm{cm}^{3} \mathrm{~g}^{-}\right.\end{array}$ \\
\hline SBA-15 & - & 899.1 & 0.92 & 0.18 & 1.10 \\
Cu-AA/SBA & 2.71 & 508.8 & 0.45 & 0.10 & 0.55 \\
Cu-OA/SBA & 2.78 & 588.5 & 0.52 & 0.12 & 0.64 \\
\hline
\end{tabular}

[a] SA = surface area calculated by the BET method.

[b] $\mathrm{V}_{\text {meso }}=$ mesopore volume, and $\mathrm{V}_{\text {micro }}=$ micropore volume calculated by the NLDFT method

${ }^{[c]} \mathrm{V}_{\text {total }}=$ total pore volume calculated at $\mathrm{p} / \mathrm{p}_{0}=0.99$

The catalytic activity of the CuO/SBA-15 materials was investigated for the selective oxidation of methane to methanol according to the well-known stepwise procedure first reported by Groothaert et al.. ${ }^{[7 a]}$ Typically, the catalyst was activated in oxygen at $550{ }^{\circ} \mathrm{C}$, then allowed to interact with methane at 
$200{ }^{\circ} \mathrm{C}$. The last step for extraction of methanol could be performed with either liquid water (off-line extraction) or steam (on-line extraction). For a catalytic comparison, Cu/mordenite with a Cu loading of $\sim 2.6 \mathrm{wt} . \%$ prepared by a recently reported solid-state ion exchange between $\mathrm{NH}_{4}$-mordenite and $\mathrm{Cu}(\mathrm{acac})_{2}$ was applied as a reference zeolite-based catalyst. ${ }^{[\mathrm{b}]}$

Table 2. Catalytic performances of CuO/SBA-15 materials.

\begin{tabular}{|c|c|c|c|c|c|c|c|}
\hline \multirow{2}{*}{ Entry } & \multirow{2}{*}{ Catalyst } & \multirow{2}{*}{$\begin{array}{c}\mathrm{Cu} \\
\text { loading } \\
\text { (wt.\%) }\end{array}$} & \multicolumn{3}{|c|}{$\begin{array}{c}\text { Product yield } \\
\left(\mu \mathrm{mol} \mathrm{g}_{\mathrm{cat}^{-1}}\right)\end{array}$} & \multirow{2}{*}{$\begin{array}{c}\text { Oxidized } \\
\mathrm{CH}_{4}{ }^{[\mathrm{c}]} \\
\left(\mu \mathrm{mol}^{-1}\right. \\
\left.\mathrm{g}_{\mathrm{cat}^{-1}}\right)\end{array}$} & \multirow{2}{*}{$\begin{array}{c}\text { Selectivity } \\
\text { to } \mathrm{MeOH} \\
\text { \& } \mathrm{DME}^{[\mathrm{d}]} \\
(\%)\end{array}$} \\
\hline & & & $\mathrm{MeOH}^{[\mathrm{a}]}$ & $\mathrm{DME}^{[\mathrm{b}]}$ & $\mathrm{CO}_{2}{ }^{[\mathrm{b}]}$ & & \\
\hline 1 & Cu-AA/SBA & 2.71 & 30.2 & 0 & 3.4 & 33.6 & 89.9 \\
\hline 2 & $\begin{array}{c}\text { Cu- } \\
\text { AA/SBA }\end{array}$ & 2.71 & 31.7 & 0 & 5.8 & 37.5 & 84.5 \\
\hline 3 & Cu-OA/SBA & 2.78 & 11.1 & 0 & 1.0 & 12.1 & 91.7 \\
\hline
\end{tabular}

[a] Methanol was analyzed by GC after off-line extraction with liquid water.

${ }^{[b]}$ Gas-phase products were analyzed by MS during online extraction with steam.

[c] Amount of oxidized methane was $=\operatorname{moles}(\mathrm{MeOH})+2^{*} \operatorname{moles}(\mathrm{DME})+$ $\operatorname{moles}\left(\mathrm{CO}_{2}\right)$

[d] Selectivity to $\mathrm{MeOH}$ and $\mathrm{DME}=\left[\operatorname{moles}(\mathrm{MeOH})+2^{*} \operatorname{moles}(\mathrm{DME})\right]$ moles(reacted $\mathrm{CH}_{4}$ )

${ }^{[\mathrm{e}]}$ Reused catalyst for the second cycle.

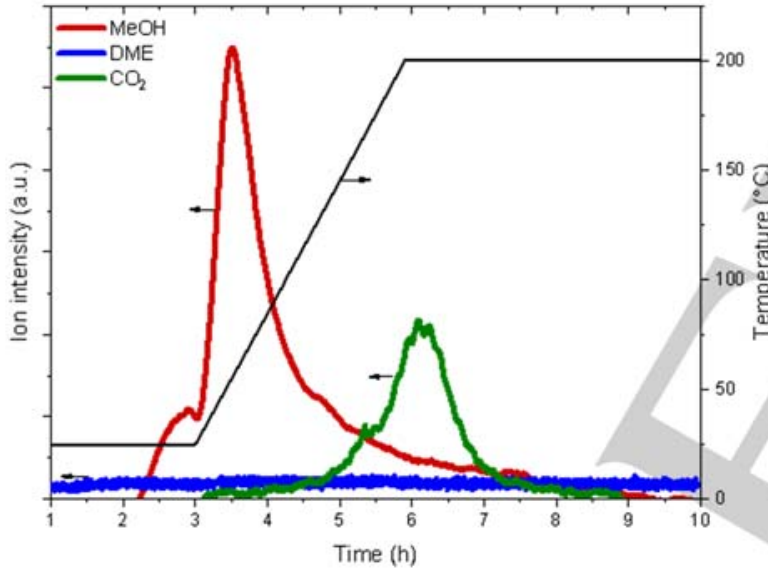

Figure 3. Mass-spectral signals of products after interaction of Cu-AA/SBA with methane at $200^{\circ} \mathrm{C}$, followed by online extraction in an He flow saturated with water.

After the extraction with water, methanol was detected in catalytic cycles over both $\mathrm{CuO} / \mathrm{SBA}-15$ catalysts indicating that methane was indeed activated by $\mathrm{Cu}$ sites in SBA-15 at low temperature $\left(200{ }^{\circ} \mathrm{C}\right)$ and then converted to methanol upon the treatment with water (Table 2). Cu-AA/SBA yielded $30.2 \mu \mathrm{mol}$ $\mathrm{g}_{\mathrm{cat}}{ }^{-1}$ of methanol (Table 2, Entry 1) while a lower methanol amount of $11.1 \mu \mathrm{mol} \mathrm{g}_{\mathrm{cat}}{ }^{-1}$ was produced over Cu-OA/SBA (Table 2, Entry 3). The increased production of methanol over $\mathrm{Cu}-\mathrm{AA} / \mathrm{SBA}$ is attributed to the high dispersion of $\mathrm{Cu}$ species in the SBA-15 framework. Similar to our previous report on $\mathrm{Cu} /$ mordenite, $\mathrm{CO}_{2}$ was observed when the extraction was performed over $100{ }^{\circ} \mathrm{C}$ (Figure 3). Notably, the selectivity toward methanol in the reaction using the CuO/SBA-15 catalysts (> $84 \%$ ) is comparable to the results obtained with $\mathrm{Cu} / \mathrm{mordenite.}$ DME could be considered as a side product by the acidic zeolite-catalyzed dehydration of in situ-produced methanol as the extraction with steam is performed at an elevated temperature $\left(\geq 135^{\circ} \mathrm{C}\right) \cdot .^{[6 a, 7 b]}$ However, our earlier study with the $\mathrm{Cu} /$ mordenite catalyst showed that methanol and DME were detected at room temperature, suggesting that different intermediates were generated on the catalyst surface, which would be transformed into methanol and dimethyl ether, respectively, by treatment of the catalyst with steam. ${ }^{[8 b]}$ In this study, no DME was produced over CuO/SBA-15 catalysts compared to $1.6 \mu \mathrm{mol} \mathrm{g} \mathrm{gat}^{-1}$ of DME obtained in the catalytic cycle using $\mathrm{Cu} /$ mordenite (Table $\mathrm{S} 1$ ). To investigate the mechanism of formation of DME on the Cu-based catalysts, an online extraction of the samples with a methanol-saturated $\mathrm{He}$ flow at room temperature was performed after their interaction with methane.

Table 2. Production of DME by online extraction at room remperature with different solvents..

\begin{tabular}{cccc} 
& & \multicolumn{2}{c}{ DME amount produced ${ }^{[\mathrm{ad}}\left(\mu \mathrm{mol} \mathrm{\textrm {gat } ^ { - 1 } )}\right.$} \\
\cline { 3 - 4 } Entry & Catalyst & $\begin{array}{c}\text { Online extraction } \\
\text { with steam }\end{array}$ & $\begin{array}{c}\text { Online } \\
\text { extraction with } \\
\text { methanol vapor }\end{array}$ \\
\hline 1 & Cu-AA/SBA & 0 & 27.6 \\
\hline 2 & Cu/mordenite & 1.6 & 48.6 \\
\hline
\end{tabular}

[a] Analyzed by MS

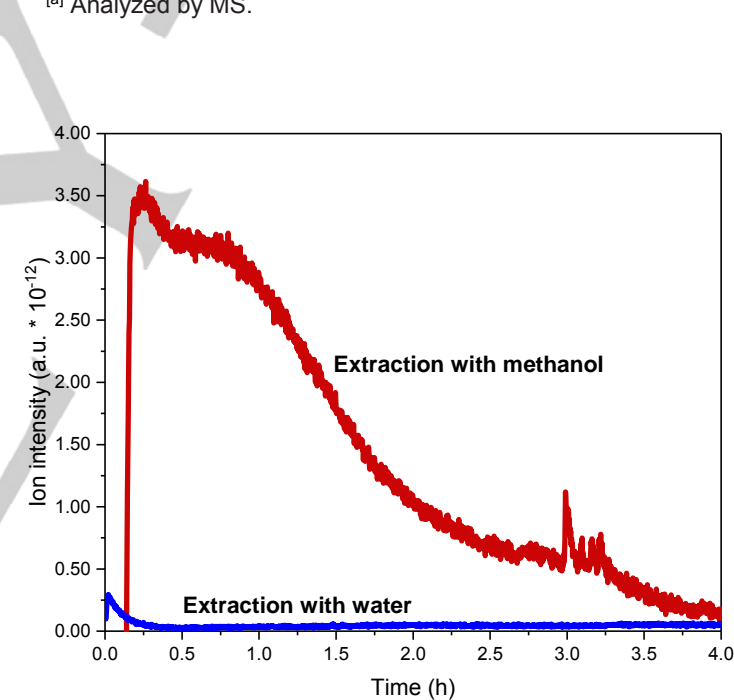

Figure 4. Comparison of mass-spectral signals of DME extracted from $\mathrm{Cu}$ $\mathrm{AA} / \mathrm{SBA}$ in the online stage at room temperature using different solvents.

Notably, $27.6 \mu \mathrm{mol} \mathrm{g}_{\mathrm{cat}}{ }^{-1}$ of DME were achieved with Cu-AA/SBA after the treatment with methanol vapor (Table 3). Also, the production of DME on $\mathrm{Cu} /$ mordenite was remarkably increased to $48.6 \mu \mathrm{mol} \mathrm{g} \mathrm{cat}^{-1}$. These DME yields are close to the methanol amounts produced upon the water-mediated extraction, indicating that DME obtained in the experiment with a methanolsaturated inert flow is a product of the reaction of methanol molecules applied in the extraction protocol with the bound intermediate species. It can be thus concluded that the intermediate is indeed a methoxy species bound on the catalyst surface after the reaction of active $\mathrm{Cu}$ species with methane (Scheme 1). The rate of such a reaction could be significantly enhanced by acidic sites, which are abundantly available in zeolite catalysts. The MS detected signals of DME with $\sim 30$ 
times higher intensities for $\mathrm{Cu} /$ mordenite after its contact with the methanol-saturated $\mathrm{He}$ flow compared to the results obtained from Cu-AA/SBA (Figure 4 and S6, red curves). Furthermore, DME can be also produced in an online extraction stage with water due to the attack of in situ-produced methanol on unreacted intermediate species. Such as-formed methanol species will be retained for a longer time within the zeolite framework mainly possessing micropores in comparison with the mesoporous SBA-15 material. This can explain the small amount of DME generated along with methanol over $\mathrm{Cu} /$ mordenite in the steam-assisted extraction step at room temperature.

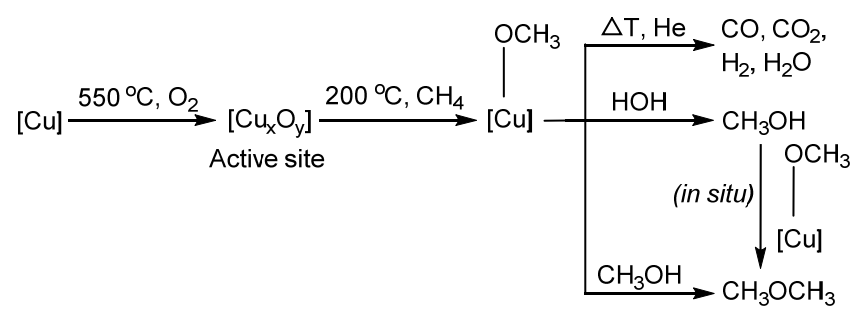

Scheme 1. Proposed formation of products on the Cu-based catalyst based on the former studies ${ }^{[8 a, 8 b, 11]}$ and mass spectrometry.

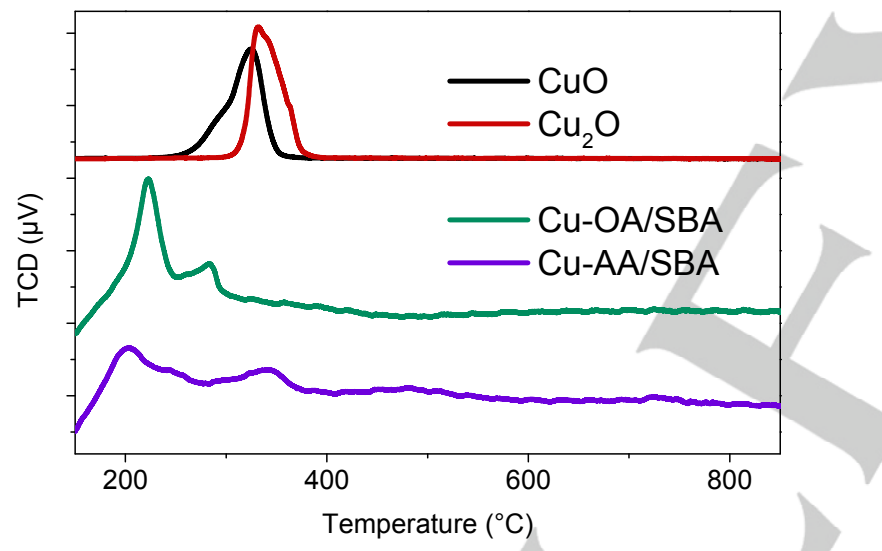

Figure 6. $\mathrm{H}_{2}$-TPR profiles of $\mathrm{Cu}$ oxides, calcined $\mathrm{Cu}-\mathrm{OA} / \mathrm{SBA}$ and calcined $\mathrm{Cu}$ AA/SBA.

To gain more insight into the location of the Cu sites in SBA-15, $\mathrm{H}_{2}$-TPR measurements were performed for both $\mathrm{CuO} / \mathrm{SBA}-15$ materials in comparison with the $\mathrm{H}_{2}$-TPR results of $\mathrm{Cu}$ oxide standards. The first reduction stage for $\mathrm{CuO} / \mathrm{SBA}-15$ samples is observed from 200 to $300{ }^{\circ} \mathrm{C}$, which is attributed to $\mathrm{CuO}$ nanoparticles on the surface and at the facilely accessible mesopores of SBA-15 (Figure 5). Most of $\mathrm{Cu}$ species in $\mathrm{Cu}$ OA/SBA-15 were reduced by $\mathrm{H}_{2}$ in this temperature range, consistent with above characterization results that large $\mathrm{CuO}$ nanoparticles are the phase of $\mathrm{Cu}$ in this sample. Besides, further $\mathrm{H}_{2}$ reduction steps at $350^{\circ} \mathrm{C}$ and $500{ }^{\circ} \mathrm{C}$ are found for the $\mathrm{Cu}-\mathrm{AA} / \mathrm{SBA}$ sample, indicating that $\mathrm{Cu}$ species can be distributed at less accessible sites of SBA-15, namely micropores in the main-channel wall, by using $\mathrm{Cu}(\mathrm{acac})_{2}$ for the preparation of $\mathrm{CuO} / \mathrm{SBA}-15$. It is therefore suggested that the formation of smaller $\mathrm{CuO}$ clusters in Cu-AA/SBA led to the better catalytic performance of $\mathrm{Cu}-\mathrm{AA} / \mathrm{SBA}$ compared to the result obtained with $\mathrm{Cu}-\mathrm{OA} / \mathrm{SBA}$. Calculation of $\mathrm{H}_{2}$ consumption in the TPR measurements further indicates that after activated in $\mathrm{O}_{2}$, the samples indeed contain $\mathrm{Cu}$ (II) species only as found in $\mathrm{Cu} /$ zeolites, which are responsible for activation of methane in the earlier studies. ${ }^{[6 a, 7 d, 8 b, 12]}$

Since the first report on the stepwise manner for the gas-phase direct production of methanol from methane over Cu-exchanged zeolites, ${ }^{[7 a]}$ only zeolites and zeotypes have been used as supports for preparation of Cu-based catalysts. In spite of many attempts over the last decade, the nature of active species in the $\mathrm{Cu} /$ zeolite catalysts has been still unknown. ${ }^{[\mathrm{Ba}]}$ Based on both theoretical and spectroscopic analyses, several different structures of $\mathrm{Cu}$ sites, which can be activated in $\mathrm{O}_{2}$ and subsequently be able to react with methane molecules, have been suggested using a zeolitic model with a cationexchangeable framework. ${ }^{[8 e,}$ 13] In situ UV-vis spectroscopy analysis is known as one of the essential characterization techniques to yield more information on the activated $\mathrm{Cu}$ sites. In earlier studies, the UV-vis spectra of $\mathrm{O}_{2}$-activated Cu/ZSM- 5 and $\mathrm{Cu} /$ mordenite showed a band at $\sim 22500 \mathrm{~cm}^{-1}$, whose intensity of which is rapidly decreasing when methane was purged to the samples. $\left.{ }^{[7 a}, 8 d, 14\right]$ This band is assigned to an active site of monooxo-dicopper $\left(\mu-\mathrm{Cu}_{2} \mathrm{O}\right) \cdot{ }^{[15]}$ However, several studies have recently reported the absence of this band for $\mathrm{Cu} /$ mordenite during the $\mathrm{O}_{2}$-activation step. ${ }^{[6 a, 8 a, 8 c]}$ Instead of that, Grundner et al. reported another broad band at $\sim 31000$ $\mathrm{cm}^{-1}$ which was stable in $\mathrm{O}_{2}$ and disappeared after $30 \mathrm{~min}$ contact with methane. ${ }^{[6 a]}$ Also in this study, a $\left[\mathrm{Cu}_{3}(\mu-\mathrm{O})_{3}\right]^{2+}$ core was suggested to be responsible for the activation of methane. A similar result was further found in the very recent work by Kim et al.. ${ }^{[16]}$ In addition, several other $\mathrm{Cu}$ sites embedded in the zeolite channels have been proposed as potential cores for the activation of methane, namely a simple monocopper site, ${ }^{[17]}$ larger $\mathrm{Cu}$-oxo clusters such as $\left[\mathrm{Cu}_{4} \mathrm{O}_{4}\right]^{2+}$ and $\left[\mathrm{Cu}_{5} \mathrm{O}_{5}\right]^{2+},{ }^{[8 \mathrm{e}]}$ and even small/ultrasmall $\mathrm{CuO}$ clusters. ${ }^{[8 \mathrm{a}, 8 \mathrm{c}]}$

It should be noted that SBA-15 is known as a porous silica material without ion-exchangeable positions. Therefore, the formation of the isolated Cu-oxo species, which are defined as active sites for $\mathrm{Cu} /$ zeolites, in SBA-15 seems to be impossible. After the $\mathrm{O}_{2}$ activation up to $550{ }^{\circ} \mathrm{C}$, indeed no band in the region of $20000-25000 \mathrm{~cm}^{-1}$ was found in the in situ UV-vis spectra demonstrating the absence of the mono- $\mu$-oxo dicopper site. The spectra of the samples activated in $\mathrm{O}_{2}$ show an absorption band centered at $\sim 13000 \mathrm{~cm}^{-1}$, that is assignable to $\mathrm{d}-\mathrm{d}$ transitions of $\mathrm{Cu}(\mathrm{II})$ ions. ${ }^{[18]}$ Interestingly, similar to the results recently reported for $\mathrm{Cu} /$ mordenite ${ }^{[6 a, 16]}$ a considerable development of the broad band centered at $\sim 32000 \mathrm{~cm}^{-1}$ was observed for both Cu-AA/SBA and Cu-OA/SBA during the activation step (Figures $7 \mathrm{a}$ and $\mathrm{S7a}$ ). It should be noted that the $\sim 32000 \mathrm{~cm}^{-1}$ absorption commonly appears in UV-vis spectra of Cu-based materials due to a charge transfer of $\mathrm{O}^{2-} \rightarrow \mathrm{Cu}^{2+}$ in CuO clusters. ${ }^{[18 b, 19]}$ This increasing feature observed in the UVvis spectra of CuO/SBA-15 samples is therefore assigned to activated $\mathrm{CuO}$ species deposited on SBA-15. As can be expected, in the next step for interaction with methane at $200{ }^{\circ} \mathrm{C}$, the intensity of the $32000 \mathrm{~cm}^{-1}$ band started decreasing as methane was sent to the sample (Figures $7 \mathrm{~b}$ and $\mathrm{S} 7 \mathrm{~b}$ ), proving that the $\mathrm{O}_{2}$-activated $\mathrm{CuO}$ species are reactive with methane. Importantly, analyzing the outlet stream with the MS during the 
contact of the samples with methane revealed that water which is typically generated upon the simple reduction of $\mathrm{CuO}$ in the presence of methane at higher temperatures $\left(>500{ }^{\circ} \mathrm{C}\right),{ }^{[20]}$ and methanol were not detected. Such a decrease in the $32000 \mathrm{~cm}^{-1}$ band intensity is therefore attributed to the activation of methane by $\mathrm{CuO}$ species at $200{ }^{\circ} \mathrm{C}$, which yields the corresponding intermediate stabilized on the catalyst surface. However, the incomplete disappearance of the band after $2 \mathrm{~h}$ interaction with methane, which is more significantly observed for Cu-OA/SBA, showed that the $\mathrm{CuO}$ species in the samples consist of both active and inactive sites. In combination with the better production of methanol observed for $\mathrm{Cu}-\mathrm{AA} / \mathrm{SBA}$ and an earlier study on inactive larger $\mathrm{CuO}$ nanoparticles (30 - $60 \mathrm{~nm}$ ) supported in pure silica, ${ }^{[8 a]}$ we therefore conclude that welldispersed small $\mathrm{CuO}$ nanoparticles located within the SBA-15 framework are more active for the methane-to-methanol conversion. Also, according to the in situ UV-vis spectroscopy results of $\mathrm{Cu} /$ mordenite catalysts previously reported, ${ }^{[8 b, 8 c, 16]}$ it is suggested that $\mathrm{Cu} / \mathrm{zeolites}$ may possess both different active sites including Cu-oxo complexes stabilized by aluminum in the zeolite framework and small $\mathrm{CuO}$ nanoclusters.
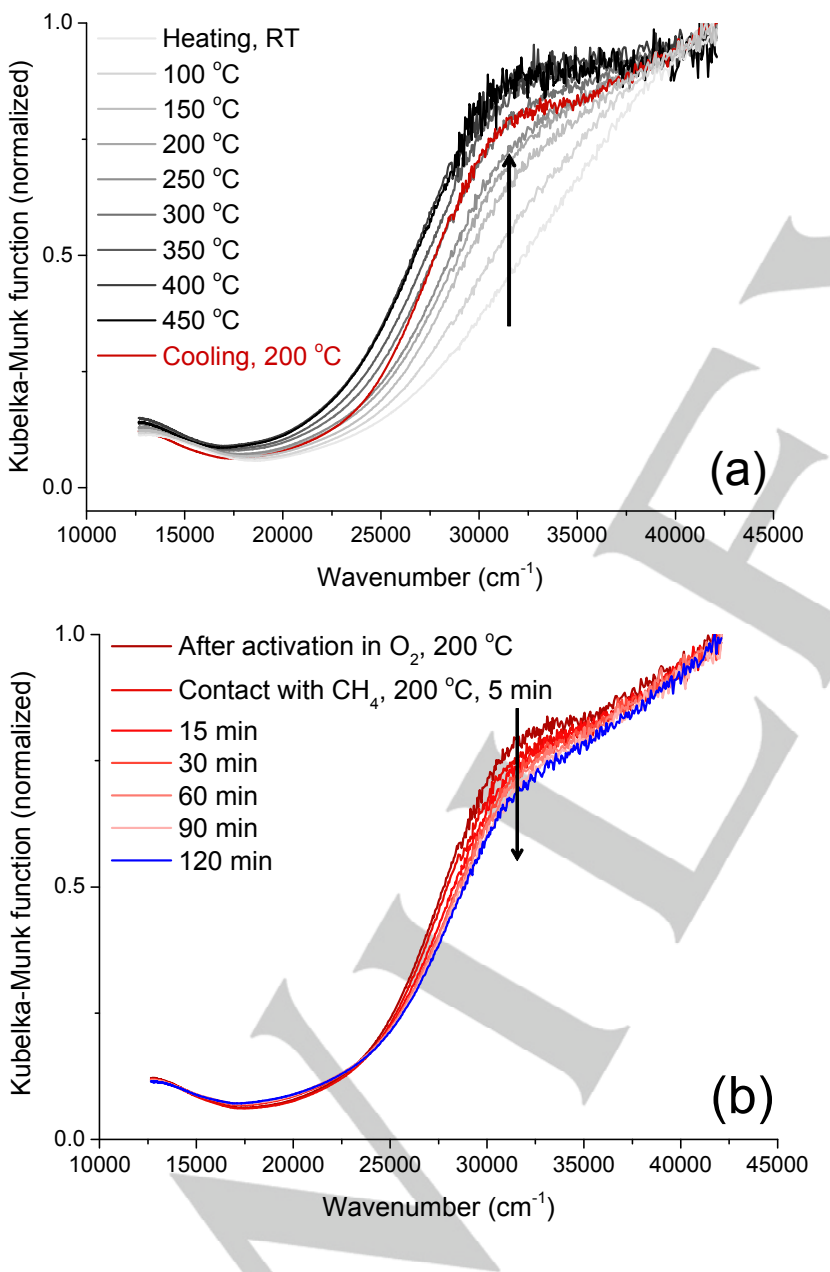

Figure 7. In situ UV-vis spectra of Cu-AA/SBA (a) after activation in $\mathrm{O}_{2}$ and (b) subsequent reaction with methane at $200^{\circ} \mathrm{C}$

In the second catalytic cycle, Cu-AA/SBA was able to produce a similar amount of methanol under the identical conditions. The mass-spectrometric analysis during the on-line extraction of products with steam also showed similar results to those of the first run (Figure S4). No considerable changes in structure and morphology of the used catalyst were found based on TEM, $\mathrm{XRD}$, and $\mathrm{N}_{2}$-sorption measurements. Therefore, it can be concluded that $\mathrm{CuO}$ species are stable in SBA-15 and can be reactivated after the first cycle.

\section{Conclusions}

CuO/SBA-15 catalysts were prepared by wet impregnation and tested for the partial oxidation of methane to methanol via a three-step manner. This study shows that methanol is indeed produced on CuO/SBA-15. CuO species are able to activate methane into methoxy species and stabilize them on the surface. Methanol or DME can be produced depending on the solvent used in the subsequent extraction step. The reactivity of $\mathrm{CuO}$ species on SBA-15 with methane was further demonstrated by the in-situ UV-vis spectroscopy measurements, in which intensity of the band centered at $32000 \mathrm{~cm}^{-1}$ increased by an $\mathrm{O}_{2}$-activation and considerably decreased after the contact with methane. The catalyst prepared from $\mathrm{Cu}(\mathrm{acac})_{2}$ had a better catalytic performance due to the high dispersion of small/ultrasmall CuO species in the SBA-15 framework compared to the $\mathrm{Cu}(\mathrm{OAc})_{2}$-based sample. However, further studies on supported $\mathrm{CuO}$ are needed to gain more insight in size of active clusters and subsequently to improve the performance. While the active sites for the hydroxylation of methane over Cu-exchanged zeolites is not fully defined, CuO/SBA-15 can be seen as a much simpler model catalyst. Based on this first demonstration, it might be worthwhile to test a variety of further porous silica or other materials as supports for $\mathrm{Cu}(\mathrm{II})$ for the challenging direct conversion of methane to methanol.

\section{Experimental Section}

\section{Synthesis of materials}

\section{Synthesis of SBA-15}

SBA-15 was prepared according to the procedure previously described. ${ }^{[9}$ 21] Typically, $\mathrm{P} 123\left(\mathrm{EO}_{20} \mathrm{PO}_{70} \mathrm{EO}_{20}, \mathrm{M}_{\mathrm{av}}=5800,2 \mathrm{~g}\right)$ were dissolved in a mixture of water $(30 \mathrm{~g})$ and a $2 \mathrm{M}$ hydrochloric acid solution $(60 \mathrm{~g})$ at 35 ${ }^{\circ} \mathrm{C}$. After vigorous stirring for $1 \mathrm{~h}$, tetraethoxysilane $(4.2 \mathrm{~g})$ was added. The resulting mixture was stirred at the same temperature for $24 \mathrm{~h}$ before aged in a Teflon-lined autoclave at $100{ }^{\circ} \mathrm{C}$ for another $24 \mathrm{~h}$. The white solid was then filtered, washed with water, dried at $105^{\circ} \mathrm{C}$ for $12 \mathrm{~h}$, and calcined under static air at $500{ }^{\circ} \mathrm{C}$ for $4 \mathrm{~h}$.

\section{Synthesis of CuOISBA-15}

A Cu-based precursor $(\mathrm{Cu}$ (II) acetylacetonate or $\mathrm{Cu}(\mathrm{II})$ acetate, 0.45 $\mathrm{mmol}$ ) was added to a mixture of SBA-15 $(0.975 \mathrm{~g})$ and absolute ethanol $(10 \mathrm{ml})$. After sonication for $10 \mathrm{~min}$, a slow evaporation of ethanol was conducted at $40{ }^{\circ} \mathrm{C}$ under vigorous stirring until a sludge-like phase was obtained. The sample was dried at $80^{\circ} \mathrm{C}$ for $12 \mathrm{~h}$ for complete removal of ethanol. The resulting powder was then pressed into pellets at 100 bar for $60 \mathrm{~s}$, lightly ground, and sieved to a 200-400 $\mu \mathrm{m}$ diameter fraction. Calcination of the material was performed under static air at $550{ }^{\circ} \mathrm{C}$ for 4 h. The Cu content in the materials was determined by inductively coupled plasma-optical emission spectrometry (ICP-OES).

Synthesis of Cu/mordenite 
$\mathrm{Cu} /$ mordenite $(2.58$ wt.\% of $\mathrm{Cu}$ ) was prepared by intensively grinding $\mathrm{Cu}(\mathrm{acac})_{2}(0.120 \mathrm{~g})$ and $\mathrm{NH}_{4}$-form mordenite $(\mathrm{Si} / \mathrm{Al}=10,0.975 \mathrm{~g})$ in a mortar within $30 \mathrm{~min}{ }^{[86],[22]}$ The resulting mixture was pressed and sieved to a 200-400 $\mu \mathrm{m}$ diameter fraction before the $\mathrm{Cu}$ exchange was performed in situ during the activation step of the catalytic testing.

\section{Catalytic test}

A U-shaped quartz reactor (ID $=6 \mathrm{~mm}$ ) was loaded with $\sim 0.6 \mathrm{~g}$ of the catalyst and placed in an oven. The catalyst bed was then treated at 550 ${ }^{\circ} \mathrm{C}\left(2^{\circ} \mathrm{C} \mathrm{min}-1\right)$ in a $50 \mathrm{Nml} \mathrm{min}{ }^{-1}$ flow of $\mathrm{O}_{2}$ for $8 \mathrm{~h}$. After cooling to $60{ }^{\circ} \mathrm{C}$ $\left(10^{\circ} \mathrm{C} \mathrm{min}^{-1}\right)$, the excess gas-phase $\mathrm{O}_{2}$ was removed by a $50 \mathrm{Nml} \mathrm{min}{ }^{-1}$ flow of $\mathrm{N}_{2}$ for $5 \mathrm{~min}$. A mixture of $5 \mathrm{Nml} \mathrm{min}^{-1} \mathrm{CH}_{4}$ and $30 \mathrm{Nml} \mathrm{min}{ }^{-1} \mathrm{~N}_{2}$ was then introduced to the reactor. The temperature was kept unchanged for 20 min before the catalyst was heated under the same flow to $200{ }^{\circ} \mathrm{C}$ with a rate of $5^{\circ} \mathrm{C} \mathrm{min}-1$. After interaction of the catalyst with methane for $60 \mathrm{~min}$, the methane-containing flow was switched off, and the catalyst bed was cooled to room temperature. For quantification of methanol, the resulting material was dispersed in $10 \mathrm{ml}$ of water under vigorous stirring for $2 \mathrm{~h}$. After centrifuging and filtration, the liquid phase was transferred to a volumetric flask, mixed with a predetermined volume of acetonitrile, as internal standard, and analyzed with a gas chromatograph (GC). Analysis of aqueous samples was performed using a Shimadzu GC 2010-Plus equipped with a flame ionization detector (FID) and a SUPELCOWAX ${ }^{\circledR} 10$ column (length $=30 \mathrm{~m}$, inner diameter $=$ $0.53 \mathrm{~mm}$, and film thickness $=1.00 \mu \mathrm{m}$ ). The oven was held at $60^{\circ} \mathrm{C}$ for $8 \mathrm{~min}$, and then heated at a rate of $30^{\circ} \mathrm{C} \mathrm{min}-1$ to $120^{\circ} \mathrm{C}$. Temperature of inlet and detector was set constant at $180^{\circ} \mathrm{C}$.

In an experiment using the online extraction method, after the interaction of the catalyst with methane for $60 \mathrm{~min}$ at $200{ }^{\circ} \mathrm{C}$, the gas stream was switched off and the catalytic bed was cooled down to room temperature. The outlet stream was connected to a quadruple mass spectrometer (MS, InProcess Instruments GAM 200). A $50 \mathrm{Nml} \mathrm{min}{ }^{-1}$ flow of watersaturated $\mathrm{He}$ flow was introduced to the reactor at room temperature for $3 \mathrm{~h}$ before the reactor was heated at a rate of $1^{\circ} \mathrm{C} \mathrm{min}-1$ to $200{ }^{\circ} \mathrm{C}$. This temperature was kept constant for another $3 \mathrm{~h}$. The temperature of the gas-washing bottle was maintained at $25{ }^{\circ} \mathrm{C}$ during the whole experiment. The products were identified based on the revolution of the signal $m / z=31,44$, and 45 characteristic for methanol, DME, and $\mathrm{CO}_{2}$, respectively. The He signal $(m / z=4)$ was used as an internal standard to quantify DME and $\mathrm{CO}_{2}$.

\section{Characterization of catalysts}

\section{Transmission electron microscopy (TEM)}

TEM and energy dispersive X-ray spectroscopy (EDX) measurements were recorded on a TECNAI G 20 S-TWIN electron microscope operated at $200 \mathrm{kV}$, equipped with an EDAX EDX system (Si(Li)) SUTW detector, energy resolution of $136 \mathrm{eV}$ (for MnK( $\alpha$ )). For sample preparation, a drop of the material dispersed in ethanol was deposited onto a carbon-coated nickel grid via evaporation.

\section{$\mathrm{N}_{2}$ sorption analysis}

$\mathrm{N}_{2}$ sorption analysis was performed at $77 \mathrm{~K}$ using a QUADRASORB SI, equipped with automated surface area analyzer. Before analysis, samples were degassed at $150^{\circ} \mathrm{C}$ for $12 \mathrm{~h}$. Specific surface area was determined over a $0.05-0.30 \mathrm{P} / \mathrm{P}$ o range by Brunauer-Emmett-Teller (BET) method. Total pore volume was collected at $P / P_{o}=0.99$. Average pore width was calculated based on non-local density functional theory (NLDFT) method.

Powder X-ray Diffraction (PXRD)
PXRD was performed with a Bruker-AXS D8 Advanced diffractometer with DAVINCI design using CuKa radiation $(\lambda=1.5418 \AA)$ equipped with a Lynx Eye detector.

In situ UV- visible (UV-vis) spectroscopy

UV-visible diffuse reflectance spectra were measured on a Cary 5000 spectrometer (Agilent) equipped with a Harrick Praying Mantis ${ }^{\mathrm{TM}}$ diffuse reflectance attachment (DRP-P72) and a reaction chamber (HVC-VUV). The in situ cell was connected to a gas delivery system for operation under flow conditions. Spectralon ${ }^{\circledR}$ was used as a white standard. Spectra were taken in the $200-800 \mathrm{~nm}$ range with a step size of $1 \mathrm{~nm}$ every 3 min during the treatment of materials. Results are shown in the Kubelka-Munk function $(F(R))$, which are calculated from the recorded reflectance data.

The in situ cell was heated to $550{ }^{\circ} \mathrm{C}$ with a rate of $10{ }^{\circ} \mathrm{C} \mathrm{min}-1$ in a 50

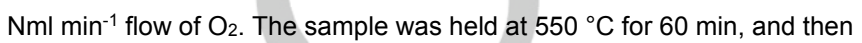
cooled to $200{ }^{\circ} \mathrm{C}$ with a rate of $10^{\circ} \mathrm{C} \mathrm{min}-1$ under the same flow. After $\mathrm{O}_{2}$ removal by a $50 \mathrm{Nml} \mathrm{min}{ }^{-1}$ flow of He for $5 \mathrm{~min}$, a mixture of $15 \mathrm{Nml} \mathrm{min}^{-1}$

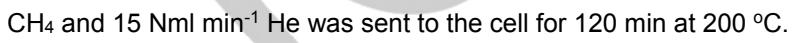

Temperature-programmed reduction by hydrogen $\left(\mathrm{H}_{2}-\mathrm{TPR}\right)$ $\mathrm{H}_{2}$-TPR experiments were conducted on a BELCAT II instrument (Version 0.4.5.13). Prior to measurements, Cu/mordenites were pretreated in a $40 \mathrm{NmL} \mathrm{min}^{-1}$ flow of $\mathrm{O}_{2}$ at $550{ }^{\circ} \mathrm{C}$ for $3 \mathrm{~h}$, and then cooled to $40^{\circ} \mathrm{C}$. $\mathrm{H}_{2}$-TPR profiles of the samples were recorded in a $30 \mathrm{NmL} \mathrm{min}^{-}$ ${ }^{1}$ flow of $5 \% \mathrm{H}_{2} / \mathrm{N}_{2}$ at a heating rate of $3{ }^{\circ} \mathrm{C} \mathrm{min}^{-1}$ up to $900{ }^{\circ} \mathrm{C}$.

\section{Acknowledgements}

This work is funded by the Cluster of Excellence Unifying Concepts in Catalysis (UniCat) and was conducted in the framework of the BasCat collaboration between BASF SE, FHI and TU Berlin. We acknowledge C. Eichenauer for $\mathrm{N}_{2}$ sorption measurements, M. Unterweger for XRD measurements, $S$. Selve and Dr. C. Göbel for TEM measurements. H. V. L would like to thank Deutscher Akademischer Austauschdienst (DAAD) for funding his Ph.D. fellowship and M. König for a valuable discussion on UV-vis analysis.

Keywords: SBA-15 - copper oxide $\cdot$ wet impregnation $•$ selective oxidation $\cdot$ methane $\cdot$ methanol

[1] a) C. Hammond, S. Conrad, I. Hermans, ChemSusChem 2012, 5, 16681686; b) P. Schwach, X. Pan, X. Bao, Chem. Rev. 2017, 117, 8497-8520.

[2] P. Tomkins, M. Ranocchiari, J. A. van Bokhoven, Acc. Chem. Res. 2017, $50,418-425$.

[3] a) A. I. Olivos-Suarez, À. Szécsényi, E. J. M. Hensen, J. Ruiz-Martinez, E. A. Pidko, J. Gascon, ACS Catal. 2016, 2965-2981; b) B. Wang, S. Albarracín-Suazo, Y. Pagán-Torres, E. Nikolla, Catal. Today 2017, 285, 147-158; c) E. V. Kondratenko, T. Peppel, D. Seeburg, V. A. Kondratenko, N. Kalevaru, A. Martin, S. Wohlrab, Catal. Sci. Technol. 2017, 7, 366-381.

[4] M. Ravi, M. Ranocchiari, J. A. van Bokhoven, Angew. Chem., Int. Ed. 2017, 56, 16464-16483.

[5] J. M. Bollinger Jr, Nature 2010, 465, 40-41.

[6] a) S. Grundner, M. A. C. Markovits, G. Li, M. Tromp, E. A. Pidko, E. J. M. Hensen, A. Jentys, M. Sanchez-Sanchez, J. A. Lercher, Nat. Commun 2015, 6, 7546; b) R. Banerjee, Y. Proshlyakov, J. D. Lipscomb, D. A. Proshlyakov, Nature 2015, 518, 431-434; c) R. Balasubramanian, S. M. Smith, S. Rawat, L. A. Yatsunyk, T. L. Stemmler, A. C. Rosenzweig, Nature 2010, 465, 115-119; d) S. I. Chan, S. S. F. Yu, Acc. Chem. Res. 2008, 41, 969-979.

[7] a) M. H. Groothaert, P. J. Smeets, B. F. Sels, P. A. Jacobs, R. A. Schoonheydt, J. Am. Chem. Soc. 2005, 127, 1394-1395; b) E. V. Starokon, M. V. Parfenov, L. V. Pirutko, S. I. Abornev, G. I. Panov, J. 
Phys. Chem. C 2011, 115, 2155-2161; c) N. V. Beznis, A. N. C. van Laak B. M. Weckhuysen, J. H. Bitter, Microporous Mesoporous Mater. 2011 138, 176-183; d) V. L. Sushkevich, D. Palagin, M. Ranocchiari, J. A. van Bokhoven, Science 2017, 356, 523-527.

[8] a) K. Narsimhan, K. lyoki, K. Dinh, Y. Román-Leshkov, ACS Cent. Sci. 2016, 2, 424-429; b) H. V. Le, S. Parishan, A. Sagaltchik, C. Göbel, C Schlesiger, W. Malzer, A. Trunschke, R. Schomäcker, A. Thomas, ACS Catal. 2017, 7, 1403-1412; c) P. Tomkins, A. Mansouri, S. E. Bozbag, F. Krumeich, M. B. Park, E. M. C. Alayon, M. Ranocchiari, J. A. van Bokhoven, Angew. Chem., Int. Ed. 2016, 55, 5467-5471; d) P. Vanelderen, B. E. R. Snyder, M.-L. Tsai, R. G. Hadt, J. Vancauwenbergh, O. Coussens, R. A. Schoonheydt, B. F. Sels, E. I. Solomon, J. Am. Chem. Soc. 2015, 137, 6383-6392; e) D. Palagin, A. J. Knorpp, A. B. Pinar, M Ranocchiari, J. A. van Bokhoven, Nanoscale 2017, 9, 1144-1153; f) G. Li, P. Vassilev, M. Sanchez-Sanchez, J. A. Lercher, E. J. M. Hensen, E. A Pidko, J. Catal. 2016, 338, 305-312.

[9] J. Zhu, K. Kailasam, X. Xie, R. Schomaecker, A. Thomas, Chem. Mater 2011, 23, 2062-2067.

[10] Q. Yang, F. Gu, Y. Tang, H. Zhang, Q. Liu, Z. Zhong, F. Su, RSC Adv. 2015, 5, 26815-26822.

[11] E. M. C. Alayon, M. Nachtegaal, A. Bodi, J. A. van Bokhoven, ACS Catal. 2014, 4, 16-22.

[12] R. A. Himes, K. D. Karlin, Proc. Natl. Acad. Sci. 2009, 106, 18877-18878.

[13] a) M. H. Mahyuddin, A. Staykov, Y. Shiota, M. Miyanishi, K. Yoshizawa, ACS Catal. 2017, 7, 3741-3751; b) P. J. Smeets, M. H. Groothaert, R. A. Schoonheydt, Catal. Today 2005, 110, 303-309; c) M. H. Mahyuddin, A. Staykov, Y. Shiota, K. Yoshizawa, ACS Catal. 2016, 6, 8321-8331.

[14] P. Vanelderen, R. G. Hadt, P. J. Smeets, E. I. Solomon, R. A. Schoonheydt, B. F. Sels, J. Catal. 2011, 284, 157-164.

[15]J. S. Woertink, P. J. Smeets, M. H. Groothaert, M. A. Vance, B. F. Sels, R. A. Schoonheydt, E. I. Solomon, Proc. Natl. Acad. Sci. 2009, 106, 1890818913.

[16] Y. Kim, T. Y. Kim, H. Lee, J. Yi, Chem. Commun. 2017, 53, 4116-4119.

[17] A. R. Kulkarni, Z.-J. Zhao, S. Siahrostami, J. K. Nørskov, F. Studt, ACS Catal. 2016, 6, 6531-6536.

[18] a) M. J. Wulfers, S. Teketel, B. Ipek, R. F. Lobo, Chem. Commun. 2015, 51, 4447-4450; b) C.-H. Liu, N.-C. Lai, J.-F. Lee, C.-S. Chen, C.-M. Yang, J. Catal. 2014, 316, 231-239; c) K. Narsimhan, V. K. Michaelis, G. Mathies, W. R. Gunther, R. G. Griffin, Y. Román-Leshkov, J. Am. Chem. Soc. 2015, 137, 1825-1832; d) P. Vanelderen, J. Vancauwenbergh, M. L. Tsai, R. G. Hadt, E. I. Solomon, R. A. Schoonheydt, B. F. Sels ChemPhysChem 2014, 15, 91-99.

[19]a) M. C. N. A. de Carvalho, F. B. Passos, M. Schmal, Appl. Catal., A 2000 193, 265-276; b) Z. R. Ismagilov, S. A. Yashnik, V. F. Anufrienko, T. V. Larina, N. T. Vasenin, N. N. Bulgakov, S. V. Vosel, L. T. Tsykoza, Appl. Surf. Sci. 2004, 226, 88-93; c) S. L. Nauert, F. Schax, C. Limberg, J. M. Notestein, J. Catal. 2016, 341, 180-190.

[20]a) E. R. Monazam, R. Siriwardane, R. W. Breault, H. Tian, L. J. Shadle, G. Richards, S. Carpenter, Energy Fuels 2012, 26, 2779-2785; b) J. Adánez, P. Gayán, J. Celaya, L. F. de Diego, F. García-Labiano, A. Abad, Ind. Eng Chem. Res. 2006, 45, 6075-6080; c) N. Guilhaume, M. Primet, J. Chem. Soc., Faraday Trans. 1994, 90, 1541-1545.

[21] D. Zhao, J. Feng, Q. Huo, N. Melosh, G. H. Fredrickson, B. F. Chmelka, G. D. Stucky, Science 1998, 279, 548-552.

[22] C. Hammond, M. M. Forde, M. H. Ab Rahim, A. Thetford, Q. He, R. L. Jenkins, N. Dimitratos, J. A. Lopez-Sanchez, N. F. Dummer, D. M Murphy, A. F. Carley, S. H. Taylor, D. J. Willock, E. E. Stangland, J. Kang H. Hagen, C. J. Kiely, G. J. Hutchings, Angew. Chem., Int. Ed. 2012, 51, 5129-5133. 


\section{Table of Contents}

\section{FULL PAPER}

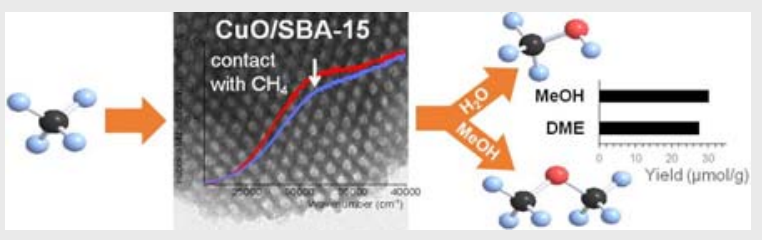

Cu-containing mesoporous SBA-15 was used for the first time as an efficient catalyst for the stepwise synthesis of methanol from methane with high selectivity (> 84\%) toward methanol and activity well comparable to the Cu-based zeolites so far reported. Formation of the products dependent on the solvent used in the subsequent extraction step was investigated (see picture).
Ha V. Le, Samira Parishan, Anton Sagaltchik, Hamideh Ahi, Annette Trunschke, Reinhard Schomäcker, and Arne Thomas*

Page No. - Page No.

Stepwise methane-to-methanol conversion on CuO/SBA-15 